\title{
Deliberative Capacity of Individuals - Dimensions and Determinants
}

\author{
Krister Lundell \\ Department of Political Science \\ Åbo Akademi University, Finland \\ krister.lundell@abo.fi
}

\begin{abstract}
This essay deals with an area of deliberative democracy where research has hitherto been limited: individual deliberative capacity. The main objective of the study is to define and create a concept and a measure of deliberative capacity of individuals; in addition, some determinants of deliberative capacity are examined. The purpose of and the very meaning of deliberative democracy, and what deliberation requires from the citizen constitute the point of departure in developing the dimensions of deliberative capacity. The aim is to capture the cognitive and attitudinal characteristics that are beneficial to deliberation, such as respectful, reciprocal, tolerant, empathic and openminded; that is, characteristics that largely define a "deliberative citizen". Three dimensions are elaborated, labeled generalized trust, equality and otherregarding ability. In order to examine the concept empirically, the dimensions are transformed into an index of deliberative capacity by means of survey data from the European Social Survey 2008. The regression analysis suggests that education is the most important socio-demographic variable; women also have more deliberative capacity than men. Non-institutionalized political participation clearly surpasses electoral and associational activity as a determinant of deliberative capacity. Naturally, political interest enhances capacity, whereas internal efficacy is of modest importance.
\end{abstract}

Keywords: deliberative capacity, deliberative democracy, generalized trust, equality, other-regarding ability

\section{INTRODUCTION}

At the end of the last century, there was a deliberative turn in democratic theory, and by now deliberative democracy has become the most active field of political theory in its entirety (Dryzek, 2007: 237). While there is a rich theoretically oriented literature on deliberative democracy, systematic empirical research on different aspects of deliberation has lagged behind. Today, however, as Dryzek points out, "...research on deliberative democracy is at the cutting edge of the integration of political theory and empirical social science" (2007: 250). For instance, several studies have dealt with the effects of deliberation, notably changes in participants' opinions and knowledge (e.g. Luskin et al., 2002). Some researchers have studied the dynamics of deliberative processes and the quality of deliberation (e.g. Steenbergen et al., 2003), whereas others have focused on the civic impact of deliberation (e.g. Morrell, 2005; Mendelberg and Karpowitz, 2007; Grönlund et al., 2010). Moreover, there are studies that concentrate on what kind of people take part in discursive participation, on the one hand, and who is willing to deliberate, on the other (Jacobs et al., 2009; Neblo et al., 2010). 
This article deals with the deliberative capacity of individuals - an area of deliberative democracy where the theoretical as well as the empirical research is still limited. The paper aims at making a contribution to both, yet the main purpose of the study is to define and create a concept and a measure of individual deliberative capacity. The concept of deliberative capacity that is developed consists of three interrelated dimensions that embody essential cognitive and attitudinal characteristics, labeled generalized trust, equality and other-regarding ability. An index of deliberative capacity, consisting of seven values, is constructed by means of survey data (European Social Survey). Having conducted statistical bivariate analyses for deliberative capacity as well as the three dimensions separately, OLS regression analysis is applied when determinants are examined.

Deliberative capacity is actually a term designed for societies rather than individuals. The term was introduced by Dryzek who defines it as "the extent to which a political system possesses structures to host deliberation that is authentic, inclusive and consequential" (2009: 1382). Authenticity means that deliberation has to induce reflection without coercion, claims have to be connected to general principles, and the process has to be reciprocal. Domination via propaganda, manipulation, threats, indoctrination, deception, expressions of mere self-interest, and the imposition of ideological conformity needs to be absent (Dryzek, 2000: 8). Inclusiveness means that a wide range of interests, opinions and preferences has to be taken into consideration. Without inclusiveness, there may be deliberation but not deliberative democracy. Thirdly, a deliberative process that is consequential has an impact on collective decisions and social outcomes.

However, there are some important elements of deliberation - other-regarding ability in particular - that cannot really be captured and measured at the societal level. A society is not other-regarding but the individuals in society may be. Therefore, without depreciating the model of deliberative capacity described above, we need to examine deliberative capacity at the individual level. Individual deliberative capacity is to a considerable extent something else than the deliberative capacity of a political system. The individual deliberative capacity is what each participant brings into a deliberative discussion, and it affects the quality of deliberation that takes place among the participants, whereas societal deliberative capacity is concerned with the public and the empowered space, transmission and accountability between these two spheres, and the extent of decisiveness in the whole system.

\section{Deliberative Democracy}

Deliberative democracy is a distinctive interpretation of democracy where free and public reasoning among equals is central to the process of decision-making. A major contrast to representative (aggregative) democracy is that the matter of results being reasonable must play a role in the process itself (Cohen, 2007: 220-21). The opinion that eventually forms the basis of decision-making is developed through discussion and respectful interaction between equal individuals in public (Barber, 1984; Gutmann and Thompson, 1996). In a deliberative process, by contrast with aggregative democracy, opinions, values and preferences may change and eventually result in a common agreement. Correction, revision and transformation of opinions as well as respectful and mutual argumentation constitute the basis of the deliberative process (Rosenberg, 2007).

In a free and open conversation, different proposals are reflected upon and opinions may be transformed for the sake of the common good. According to most theorists, political equality and the nature of the democratic dialogue are defining characteristics of deliberative 
democracy. All opinions need to be pondered over, the process must not be manipulated, and mutual understanding is a primary goal (Smith and Wales, 2000; Smith, 2005). A process where everyone justifies his/her own political views and considers the arguments of others is believed to transform individual values and preferences towards a more collective understanding - therefore, decisions based on public deliberation should be perceived by all participants as more legitimate, rational and fair than decisions based on individual preferences (Rosenberg, 2007; Grönlund et al., 2009). Deliberative theorists argue that deliberative democracy to a greater extent than other forms of democracy realizes basic democratic values such as autonomy and equality. Taken together, it is believed to improve the quality of decisions and to enrich democracy (Stokes, 1998).

\section{Empirical Research With Relevance To Deliberative Capacity}

In the volume Talking Together, Jacobs, Cook and Delli Carpini (2009) analyze how and why citizens talk to each other, who is actively involved in the conversation, and what difference it makes. The crucial point is whether citizens are capable of self-government. On the basis of new empirical data, in settings ranging from one-on-one conversations to more formal gatherings, the authors find that in as much as eight out of ten Americans regularly take part in public discussions about important political, economic and societal issues. They conclude, on the one hand, that discursive participation is more common than previously assumed. The study challenges the notion that the crisis of democracy is attributed to lazy, withdrawn and incompetent citizenry, as well as the conception that public deliberation is elitist, exclusionary and politically insignificant. On the other hand, they also conclude that public deliberation falls short of the expectations of its most enthusiastic promoters concerning universal, representative and rational communication and outcomes leading to agreement and politically efficacious citizens. Nevertheless, their study shows that ordinary citizens to a great extent have the capacity to engage with one another about demanding policy issues.

Himmelroos (2012) has conducted a study of the activity and discourse quality among deliberators, based on a deliberative mini-public experiment held in Turku, Finland 2006. Regarding the discourse quality, a modified version of the Discourse Quality Index (Steiner et al. 2004) - originally developed as a technique for measuring the deliberative quality in parliamentary debates - is applied. The modified index consists of the following categories: level of justification, content of justification, respect, and reciprocity. These dimensions capture the coherence of arguments, the reason behind one's argumentation, how empathic and considerate participants are of each other, and how participants treat arguments that contradict their own views. Accordingly, discourse quality is to a great extent concerned with the capacity to deliberate. The determinants examined include some socio-demographic characteristics, associational activity, knowledge, political efficacy and opinion intensity. Himmelroos finds that elder, male and highly educated citizens take more actively part in the discussion. However, when the other determinants are controlled for, only the effect of gender remains significant among the socio-demographics. Internal efficacy also has an impact on activity. ${ }^{1}$ Concerning discourse quality, age is the only relevant socio-demographic variable. Younger participants display better discourse quality, whereas elder people to a lesser extent motivate their own beliefs and make reference to the common good or the demand of others. Knowledge also enhances the quality of deliberation.

\footnotetext{
${ }^{1}$ By contrast, according to one study, participation in a deliberative discussion does not increase internal efficacy (Grönlund et al 2010).
} 
In an article entitled "Who Wants to Deliberate - And Why?" Neblo, Esterling, Kennedy, Lazer and Sokhey (2010) examine who is willing to deliberate and its determinants, using survey data from the US. One distinguishing feature of deliberation compared to traditional forms of political participation is that it is cognitively effortful. Therefore, in addition to demographic, resource and engagement determinants, which are derived from research on traditional political participation, the authors include correlates of motivation that are associated with the kinds of demands typical of deliberative participation. Conflict avoidance is a feature that is assumed to decrease the propensity to deliberate, whereas the personality variables need for cognition and need to evaluate should be positively related to deliberative participation. Political efficacy should likewise be a prerequisite of the willingness to deliberate, because deliberative forums are designed to be opportunities to reduce feelings of disillusion and powerlessness. Political interest and need for cognition are the most important antecedents of motivation. Conflict avoidance and need for judgment are also of some relevance, whereas efficacy is not significantly related to hypothetical willingness to deliberate. However, in an analysis based on another survey where citizens were offered the opportunity to participate in an online deliberative forum with their members of Congress to discuss immigration policy, political efficacy is one of the main determinants. The authors also find that those less likely to participate in traditional party-based politics are most interested in participating in deliberative politics.

There is a difference between the ability to deliberate and the willingness to deliberate, even though they may be closely related. Some individuals have the cognitive prerequisites to effectively participate in a deliberative process but may lack the motivation to do so, while others would like to take part in deliberative activities but may be incapable of discussing politics on equal terms with others, interpreting new facts with an open-mind, and being otherregarding and tolerant towards people that are different and/or have different points of view. We may assume that many people who to a great extent share the values that define deliberative democracy also have the willingness to deliberate; on the other hand, it is obvious that the capacity to deliberate is not equivalent to the propensity to deliberate. Attitude may be related to deliberative capacity as well as deliberative propensity. A positive attitude towards discussing political matters is, of course, a precondition for the willingness to be part of a deliberative process. In this study, however, a positive attitude is foremost associated with particular attitudinal characteristics, such as being tolerant and open-minded, which are essential ingredients of the individual capacity to deliberate.

One problem with regard to empirical research on deliberative democracy is the difficulty in combining normative theory with empirically testable theories. Too often theorists and empiricists have talked past each other (Thompson, 2008: 498). As Mutz says, "How can we take what has been, by its origins, a normative theory and turn it into an empirically testable theory?" (2008: 522). She advocates transformation of deliberative theory into middle-range theory by replacing vaguely defined entities with more concrete, circumscribed concepts, and by testing theoretically and empirically grounded hypotheses about specific associations between these concepts. A "middle-range" approach can be described as a means of bridging the gap between theory and empirical evidence (ibid.).

Furthermore, deliberative theories often involve a great deal of conceptual ambiguity as to what should qualify as deliberation. They frequently conflate defining criteria of deliberation and its beneficial consequences; thus the independent variable is defined in terms of its hypothesized effects. Deliberative theorists often seem to assume that good deliberation will 
automatically result in good things such as greater levels of trust, public-spirited attitudes, opinion consistency, faith in democratic processes, greater interest in political participation, and even better citizens. This circularity makes it impossible to empirically test the allegedly positive claims of deliberative theory (Mutz, 2008: 527). I believe that to create a measurable concept of individual deliberative capacity, we need to start with the meaning and purpose of deliberation and what it requires from the deliberator.

\section{The Purpose of Deliberation}

True deliberation is assumed to produce several beneficial results, many of which remain to be proved. If public deliberation is appropriately empathic, egalitarian, reciprocal, open-minded and reason-centered, it is expected to lead to a variety of positive democratic outcomes (Mansbridge, 1983; Barber, 1984; Cohen, 1989; Warren, 1992; Benhabib, 1996; Gutmann and Thompson, 1996; Fishkin, 1997). Real deliberation will lead to a more empathic view of other people, a better-informed perspective on common problems, and a broader understanding of one's own as well as others' interests (Mendelberg, 2002: 153). Citizens will become more involved in civic affairs (Barber, 1984), and tolerance for opposing views will increase (Gutmann and Thompson, 1996). Political decisions will be more considered and based on relevant reasons and evidence (Chambers, 1996), the community's social capital will increase (Putnam, 2000), and satisfaction with the democratic process will be enhanced when people feel that their government truly is "of the people" (Fishkin, 1997). As Mendelberg summarizes, "deliberation is expected to lead to empathy with the other and a broadened sense of people's own interests through an egalitarian, openminded and reciprocal process of reasoned argumentation" (2002: 153).

Gutmann and Thompson (2004: 3) argue that the most important characteristic of deliberative democracy is its reason-giving requirement. Reasons should appeal to principles of fair terms of cooperation and express the value of mutual respect. Moreover, reasons given in a deliberative process should be accessible to all the citizens to whom they are addressed. Thirdly, the deliberative process should aim at producing decisions that are binding for some period of time. Their fourth characteristic, neglected by most of its proponents, is that deliberative democracy is dynamic (2004: 3-6). Moreover, they identify four aims of deliberative democracy: (1) to promote the legitimacy of collective decisions; (2) to encourage public-spirited perspectives on public issues; (3) to promote mutually respectful processes of decision-making; (4) and to help correct mistakes in collective actions that stem from incomplete understanding (2004: 10-12).

In a normative sense, Parkinson (2006: 3-4) maintains, deliberative democracy implies reasoning between people in a public environment. Moreover, democratic deliberation comprises binding collective decisions, responsiveness to reflective public wishes, and the political equality of all participants. In the light of these definitions, deliberative capacity becomes a question of what is required from the citizens in a deliberative process. If participants are to persuade others and find "the better argument", all arguments must be made in public so that preferences that are vague, unreflective and ill-informed can be transformed into more firm, reflective and other-regarding ones (Cohen, 1989). Such transformation presupposes, first, that participants are communicatively competent; i.e. they can understand and critically estimate the arguments of others, and make well-founded arguments of their own. Secondly, participants have to be willing to be persuaded, and to have their preferences challenged and transformed in the face of a better argument. In other words, they must be able to set aside strategic concerns and behavior in the pursuit of their own preferences if faced by more reflective, informed and other-regarding arguments (Dryzek, 2000: 2; Parkinson, 2006: 4). 
Delli Carpini, Cook and Jacobs (2004: 328) put forward that the capacity of citizens to effectively participate is central to the democratic potential of deliberation. Some critics argue that the majority of citizens lack the capacity and/or opportunities to effectively participate in public deliberation (2004: 321). Advocates of deliberative democracy, by contrast, believe that citizens do have the capacity to efficaciously deliberate, provided that deliberative institutions are properly designed. Regardless, we may with good reason assume that the deliberative capacity varies between citizens.

In a conference paper from 2007, Zsuzsanna Chappell provided a critical assessment of the preconditions for introducing large-scale deliberative reform to existing democracies, distinguishing three interrelated levels: individuals, society and political institutions. Two broad areas at the individual level were addressed: ability and motivation of an average citizen to take part in deliberative procedures. This is similar to the distinction between deliberative capacity and deliberative propensity that was described earlier. Chappell emphasized that deliberation is a demanding activity; participants need to perform a multitude of cognitively complex tasks. Individuals have to understand arguments, they must be capable of making well-reasoned arguments, and they must be open to new arguments. They have to be able to interpret new facts and arguments correctly and they need the ability to evaluate them critically. Chappell maintained that different people have different abilities to perform these tasks.

In addition to cognitive capacities, individuals need certain attitudes. First of all, deliberating citizens need to be tolerant towards each other; they have to give equal respect to arguments that differ from their own. The most prominent of attitudes, according to many, is being otherregarding (e.g. Elster, 1986; Mansbridge, 1990). Other-regarding is an unselfish, disinterested attitude that attaches great importance to the welfare of other members of society. Chappell maintains that an other-regarding attitude rarely comes naturally to people, and it may well be the case that it will, for most people, develop as a result of deliberative practices. Tolerance, on the other hand, should be there right from the beginning; a tolerant attitude may hopefully be sufficient to get deliberation started in the first place. Related to a tolerant attitude is the requirement of participants to be open to different ideas. Gratifyingly, there is evidence from deliberative polls, meetings, and experiments that citizens in established democracies to a great extent already possess sufficient levels of tolerance and openness needed in deliberative discussions (e.g. Fishkin et al., 2002; Gastil and Levine, 2005).

\section{Three Dimensions of Deliberative Capacity}

\section{A CONCEPT OF DELIBERATIVE CAPACITY}

Deliberative democracy is associated with certain attributes, values and abilities, such as reason-giving, egalitarian, reciprocal, tolerant, respectful, empathic, reasonable, otherregarding and open-minded. These are characteristics that individuals have more or less of; citizens that to a great extent are distinguished by these characteristics have better prerequisites for efficaciously acting in a deliberative discussion than those who to a lesser extent share these features. These cognitive and attitudinal characteristics may be captured with three dimensions, called generalized trust, equality and other-regarding ability. The dimensions are elaborated below.

\section{Generalized trust}

Trust consists of a cognitive as well as an emotional component. The cognitive element is based on estimating the risks of potential negative consequences, whereas the emotional aspect is 
manifested in the desire to trust another because of a feeling of security, although there is potential for negative consequences. To trust is to accept some share of risk for ill will of others in exchange for the benefits of cooperation (Bäck, 2011: 30-31; McKnight and Chervany, 2011; Warren, 1999: 1). To simplify, trust is the expectation of another actor's future reliability (Rothstein, 2003: 111). There are different kinds of trust, however. Although it appears logical to only trust people that you know, trust is more valuable and beneficial when it can be applied to people you do not know. It has been argued that there is a moral community spirit in the human nature which makes it easier to cooperate with foreign people, even those who belong to a different culture and religion (Uslaner, 2002: 1-2). Moral trust does not presuppose that all people are reliable under all circumstances; rather, it requires the assessment that most people are trustworthy most of the time (2002: 21-22).

Generalized trust, in particular, is regarded as important to society for several reasons. It is based upon morals as well as our collective experiences; a general conviction of the benevolence of human nature. The differences between generalized and moralistic trust is that the former goes up and down, even though it is basically stable, whereas the latter is a more enduring value. The central idea that distinguishes generalized trust from particular trust is the width of one's moralistic community spirit (2002: 26-27). Generalized trust is concerned with bridging social capital as opposed to bonding social capital, which is based upon particular trust (Putnam, 2000). Bridging social capital implies networks and relationships that connect individuals from different social, economic and cultural groups. Zsuzsanna Chappell stresses the importance of bridging social capital in deliberative democracy, since deliberation requires that people leading different lives and holding different viewpoints get together and make decisions together for the sake of the common good.

Generalized trust is to have faith in people who are different from you. Usually, we trust people like ourselves, especially persons we know well. In a deliberative discussion, however, we are interacting with people that we do not know on a personal level, and, moreover, people who may be different from us in several ways. One basic precondition for acting and cooperating with other people on an equal level is to believe that their intentions are good and that they are not guided by self-interest or trying to manipulate the deliberative process in their own favor. Believing that people in general can be trusted is a leap of faith, a moral decision that we should trust other people. It is an expression of a belief in a common core of values between all people.

\section{Equality}

One of the most profound principles in a democracy is equal consideration of the preferences and interests of all citizens. Here we may call to mind the first principle of justice by Rawls, arguably the foremost representative of the liberal perspective of deliberation: "Each person is to have an equal right to the most extensive total system of equal basic liberties compatible with a similar system of liberty for all" (Rawls, 1971: 250). All citizens must be equal in their basic liberties and political rights such as voting, political participation, freedom of speech and equality under the law.

Naturally, equality is also a defining argument of deliberative democracy: the opinion that eventually forms the basis of decision-making, or recommendation to policy-makers, is developed through discussion between free and equal individuals. The deliberation must be guided by the principle of equality. It should be observed that it does not imply equality of resources; if that were a necessary condition, deliberative democracy would fail from the beginning. Rather, it is about equal participation (Thompson, 2008: 509). Democratic deliberation is an ongoing process of mutual justification where citizens are expected to give 
reasons to one another (Gutmann and Thompson, 2004: 3, 126). When deliberating, individuals should offer reasons that can be accepted by others who are similarly interested in finding reasons that are acceptable to others - thus, citizens should pursue a kind of political reasoning that is mutually justifiable, which, in turn, presupposes that they approach each others on equal terms. The principle of equal participation in the reason-giving process must be respected, although participants may be unequal in power and prestige (Thompson, 2008: 504-05). Without willingness to give others equal opportunities, the demand of mutual respect cannot be met and no preferences are challenged in the face of better-informed arguments. Policy decisions or suggestions that are perceived as legitimate, rational and fair will hardly be made.

Even when deliberative disagreement prevails, reciprocity presupposes that individuals try to seek fair terms of cooperation among equals (Gutmann and Thompson, 1996: 53). The value of mutual respect lies at the core of deliberative democracy; it is a form of agreeing to disagree, and it requires a favorable attitude towards the persons with whom one disagrees (1996: 79). Fung (2007: 167) puts forward that deliberation should be reasonable in the sense that individuals respect the claims of others and constrain the pursuit of their own self-interest. Also, the criterion of equality requires that the individual is capable of putting oneself in another place and recognizing the differences between oneself and others (Mansbridge, 1999: 225). When citizens deliberate on equal terms, they are free to develop their political capacity as well as utilize the political capacity of others.

\section{Other-regarding ability}

Jacobs et al. argue that toleration of difference is a main component of the deliberative experience (2009: 69). For one thing, the ability to understand different people presupposes some degree of faith in people who are different from oneself. Generalized trust is not enough, however. It requires power of insight, respect for other people, internal reflection, and an open-minded attitude towards differing points of view. The valuable attitude of being otherregarding, i.e. to place high value on the well-being of others and the welfare of the community at large, as opposed to pursuing self-interest, is central to deliberation. Other-regarding capacity involves a fundamental respect for other people and their points of view - without respect and respectful consideration of other people's arguments, the bridging of different views, which is one of the main purposes of deliberation, is impossible. A person with otherregarding capacity is able to discern the difference between respectable and merely tolerable differences of opinion, and ready to change his/her mind or position if confronted by a betterinformed point of view. In fact, one purpose of deliberation is to get a better-informed perspective on common problems and a broader understanding of one's as well as others' interests. Individuals in the majority of a deliberative setting need to respect and be interested in the perspectives of the individuals in the majority and new information presented by them. Being reasonable does not only imply that one has good reasons for one's actions; it also encompasses an open attitude towards objections and alternative suggestions, and willingness to reevaluate one's position in the light of new information (Chambers, 1996). It has been argued that individuals confronted by a greater diversity of ideas tend to be more openminded, to learn more from other people, and to engage in a deeper consideration of issues (Eliasoph, 1998).

Deliberating with people that are different makes great demands on the communicative competence. Deliberative communication implies that particular interests of individuals and groups are related to more universal principles (Dryzek, 2000: 68). The key deliberative virtue 
in this regard is reciprocity: communicating and presenting arguments in terms that others can accept. The primary function of reciprocity is to regulate public reason (Gutmann and Thompson 1996: 52-56). It is one of the leading principles of deliberation, prescribing accommodation based on mutual respect. Reciprocity is manifested in the desire among individuals to justify their claims to those with whom they cooperate. It represents the capacity to seek fair terms of social cooperation among equals, even in the face of deliberative disagreement. Therefore, in addition to logical justification, arguments should have intrinsic values that make them convincing and attractive to others (Cohen, 1989). Being faced with a different perspective may bring about a modification of one's original standpoint (Bohman, 1996: 63). Hence, the ability to communicate with people that are different in a constructive manner is invaluable in a deliberative setting.

None of these three dimensions embodies the concept of deliberative capacity alone; rather, each dimension serves a purpose. Equal treatment and opportunities for all is not similar to having trust in people that are different. The fact that a person appreciates equal opportunities for all and thinks that all people should be treated equally does not necessarily mean that he/she has faith in people that are different. While the ability of being other-regarding probably requires the value of considering all people as equal, the opposite is definitely not a necessary condition, and one may trust in people that are different without being able to place high value on the welfare of others. Simultaneously, while being conceptually and theoretically distinct, they are also related to one other. To believe that most people can be trusted involves, to a considerable extent, a belief that all individuals are equal - not only those that we know but also those that we do not know and people that are different from us. Similarly, the ability of being other-regarding requires a fair share of belief that all people should be treated equally and given equal opportunities as well as a good proportion of trust in those that we are cooperating with.

\section{Index of Deliberative Capacity}

Moving from normative theory to empirical science, the crucial task is to find survey data that capture these dimensions. Dryzek (2005) has argued that standard survey methods cannot capture the inherently holistic, social and dynamic elements of deliberative opinion formation. Opinion surveys represent a culture inimical to deliberative democracy. However, in Neblo et al.'s study of the propensity to deliberate which was presented earlier, the research team claims that Dryzek's critique runs the risk of being overly dismissive (Neblo et al., 2010: 569). In the absence of more refined methods of measuring the deliberative capacity of individuals, we have to rely on survey data. This is particularly so when we need data that is comparable with regard to individuals in different countries.

Moreover, survey data has also been applied in some related areas such as political trust, political knowledge and, in particular, social capital. While political trust and the political knowledge of citizens may be determined by means of asking straightforward questions, the social capital of an individual is a more complex phenomenon. Still, survey data has been frequently applied in measuring the social capital of citizens and even countries (e.g. Putnam, 2000; Norris, 2002; Rothstein and Stolle, 2003). In empirical studies, social (generalized) trust and associational activism have almost been conventional elements of social capital; some studies also include social relations as a component of social capital. For example, Bäck (2011) creates an interaction term of these three variables in a study of social capital and political participation, employing data from ESS 2002/2003.

The data exploited in this study are taken from the European Social Survey Round $4-2008$, since it provides indicators of the dimensions of deliberative capacity elaborated above. The 
measure of deliberative capacity is made up of three variables/questions in the data set (see Appendix for details). These variables are recoded into a three-grade scale, corresponding to high, medium and low level of deliberative capacity. Thereafter, the components are added into a single index of deliberative capacity on an ordinal scale that ranges from 0 to 6 . The variables/questions are:

Generalized trust: Most people can be trusted or you can't be too careful in dealing with people Equality: It is important that people are treated equally and have equal opportunities Other-regarding ability: It is important to understand different people

The ESS4-2008 consists of 29 countries - however, only citizens living in polities with considerable experience of democracy are included. According to the Freedom House ratings, Russia is an authoritarian state, Turkey was only partly democratic in 2008, and Ukraine had been rated as free only since 2005 . Consequently, these three countries are excluded from the analysis. $^{2}$

To begin with, the consistency between the indicators of deliberative capacity is explored. As mentioned earlier, the dimensions are interrelated but at the same time each one of them serves a distinct purpose. Index construction requires some internal consistency; that is, the indicators that the index consists of have to be rather highly correlated (Mastekaasa, 1987: 170). Cronbach's Alpha is 0.334 which suggests that there is some lack of consistency; the variable that measures generalized trust correlates weakly with the other two. However, since the purpose of the study is, first and foremost, to develop a concept of deliberative capacity, generalized trust will not be removed from the empirical analysis. Rather, in addition to the index, each dimension will be analyzed separately in order to reveal differences between them. Conceptually, generalized trust is related to the other two dimensions; it is therefore suspected that the inconsistency is due to the operationalization of the dimensions. The questions as well as the response options are similar for the second and the third dimension, whereas they differ with regard to generalized trust.

$\begin{array}{crr}\begin{array}{c}\text { Table } 1 \text { Index of deliberative capacity of individuals. Frequencies. } \\ \text { Index }\end{array} & \begin{array}{r}\text { Falid Percent } \\ \text { Frequency }\end{array} & 4.0 \\ 6 & 1933 & 10.5 \\ 5 & 5069 & 19.4 \\ 4 & 9353 & 23.8 \\ 3 & 11450 & 23.0 \\ 2 & 11061 & 13.8 \\ 1 & 6660 & 5.4 \\ 0 & 2607 & 100.0 \\ \text { Total } & 48133 & \\ \text { Missing } & 1846 & \\ \text { Total } & 49979 & \end{array}$

\footnotetext{
2 Respondents from the following 26 countries are included in the study: Belgium, Bulgaria, Croatia, Cyprus, Czech Republic, Denmark, Estonia, Finland, France, Germany, Greece, Hungary, Ireland, Israel, Latvia, Netherlands, Norway, Poland, Portugal, Romania, Slovakia, Slovenia, Spain, Sweden, Switzerland, United Kingdom.
} 
In Table 1, the frequency of the index is reported. The variable is normally distributed, much due to the fact that the cut-off points between high and medium as well as medium and low capacity on each dimension created categories of more or less equal size. 4 percent of the respondents score 2 on all dimensions, i.e. they have the highest possible value on the index of deliberative capacity. The median value 3 is the most frequent one, and close to the mean 2.86 . The standard deviation of the index is 1.49 .

\section{Determinants Of Deliberative Capacity}

Now we are ready to proceed with the second part of the study, i.e. examining determinants of individual deliberative capacity. Three different kinds of determinants are included: sociodemographics, civic and political participation, and political competence. Beginning with the socio-demographic approach, many scholars have pointed out that individual characteristics such as class, education, age, gender and race constitute externally induced inequalities that affect the autonomy and capacity of the participants in a deliberative context (e.g. Mansbridge, 1983; Gutmann and Thompson, 1996: 132; Young, 1996; Rosenberg, 2007: 13). Particularly, as in other forms of political participation, education is likely to influence the ability of citizens to deliberate (Verba et al., 1995). Education gives people more sophisticated reasoning skills, and provides them with cognitive and attitudinal tools to appreciate the common good and tolerate different people. On the whole, high education is likely to make for more empathic and cognitively competent deliberators (Nie et al., 1996).

Table 2 Socio-demographic characteristics, index of deliberative capacity and index dimensions. Mean values.

\begin{tabular}{|c|c|c|c|c|}
\hline & $\begin{array}{r}\text { Deliberative } \\
\text { capacity } \\
\end{array}$ & $\begin{array}{r}\text { Generalized } \\
\text { trust }\end{array}$ & Equality & $\begin{array}{r}\text { other- } \\
\text { regarding }\end{array}$ \\
\hline \multicolumn{5}{|l|}{ Age } \\
\hline \multirow[t]{2}{*}{$15-29$} & 2.86 & 1.03 & 1.04 & 0.79 \\
\hline & (9521) & & & \\
\hline \multirow[t]{2}{*}{$30-44$} & 2.87 & 1.02 & 1.04 & 0.81 \\
\hline & $(12$ 140) & & & \\
\hline \multirow[t]{2}{*}{$45-64$} & 2.88 & 1.00 & 1.07 & 0.81 \\
\hline & $(16110)$ & & & \\
\hline \multirow[t]{3}{*}{$65-$} & 2.79 & 0.95 & 1.06 & 0.79 \\
\hline & $(10205)$ & & & \\
\hline & $* * *$ & $* * *$ & $*$ & $*$ \\
\hline \multicolumn{5}{|l|}{ Gender } \\
\hline \multirow[t]{2}{*}{ Female } & 2.92 & 0.98 & 1.10 & 0.85 \\
\hline & $(26050)$ & & & \\
\hline \multirow[t]{3}{*}{ Male } & 2.78 & 1.03 & 1.00 & 0.75 \\
\hline & $(22066)$ & & & \\
\hline & $* * *$ & $* * *$ & $* * *$ & $* * *$ \\
\hline \multicolumn{5}{|l|}{ Education } \\
\hline Less than lower & 2.62 & 0.83 & 1.06 & 0.73 \\
\hline secondary educ. & (5 992) & & & \\
\hline Lower secondary & 2.69 & 0.91 & 1.04 & 0.74 \\
\hline educ. completed & (9 415) & & & \\
\hline
\end{tabular}




\begin{tabular}{|c|c|c|c|c|}
\hline $\begin{array}{l}\text { Upper secondary } \\
\text { educ. completed }\end{array}$ & $\begin{array}{r}2.77 \\
(18921)\end{array}$ & 0.97 & 1.04 & 0.77 \\
\hline $\begin{array}{ll}\text { Post-sec. } & \text { non- } \\
\text { tertiary } & \text { educ. } \\
\text { completed } & \end{array}$ & $\begin{array}{r}2.95 \\
(1056)\end{array}$ & 1.03 & 1.05 & 0.87 \\
\hline $\begin{array}{l}\text { Tertiary education } \\
\text { completed }\end{array}$ & $\begin{array}{r}3.22 \\
(12663)\end{array}$ & 1.21 & 1.09 & 0.92 \\
\hline & $* * *$ & $* * *$ & $* * *$ & *** \\
\hline
\end{tabular}

Note: $\mathrm{N}$ in parenthesis, ${ }^{* * *}=$ significant at the 0.001 -level, ${ }^{*}=$ significant at the 0.05 -level

In Table 2, patterns of deliberative capacity with regard to age, gender and education are given. The youngest respondents in ESS4-2008 were 15 and the oldest one was, allegedly, 123 years old. The table shows mean values in four age categories. The average deliberative capacity is practically at the same level in the first three categories, whereas the category with people over 64 has a lower mean value. The difference is mainly due to a lower level of generalized trust among the oldest people. Women have a higher level of deliberative capacity than men. The level of generalized trust is somewhat higher among men but women, on the other hand, have on average more other-regarding abilities and evaluate equality and equal opportunity to a greater extent. The education variable consists of five categories. The level of deliberative capacity consistently increases from lower to higher levels of education; from 2.62 in the first category to 3.22 among those with the highest level of education. This is also true of generalized trust and other-regarding ability. By contrast, there are only differences with regard to how equality and equal opportunities are evaluated. Yet even here, those with the highest level of education score the highest mean value.

In addition to socio-demographic attributes, we may assume that political and societal activities affect the capacity to participate in deliberative practices. Three such variables are included: civic participation, electoral participation and non-institutionalized political participation. It has been argued that participation in informal and loosely structured associations and interest groups generates reciprocity and trust between people, which is regarded as necessary for a responsive and vigorous democracy. Voluntary organizations infuse in their members habits of cooperation and public-spiritedness, and function as "schools of democracy", where social and civic skills necessary to partake in public life are taught (Putnam, 2000: 338). In the volume Talking Together, Jacobs et al. (2009) find a positive effect of organizational membership on discursive participation. A dummy variable is used in the analysis below, distinguishing between those who take part and those who do not take part in such activities. Conventional political participation, foremost expressed by voting in elections, may also have an impact on the capacity to deliberate. In order to make a reasonable choice, people need to gather information about politics and societal affairs, which in turn is a prerequisite for taking part in discussions on politics. A related argument is that participation in one form of politics breeds participation in other forms of politics. Having voted or not in the last parliamentary elections constitutes a dummy variable in the analysis.

However, deliberative capacity is largely regarded as an alternative to traditional political participation. Similarly, non-institutionalized political participation is an alternative to traditional forms of participation associated with political parties, and while voter turnout has decreased in Western democracies during the last few decades, more people than ever before are engaged in non-institutionalized participation such as taking part in demonstrations, 
signing petitions and boycotting products and services for political or ethical reasons. Many decades ago, this form of participation was considered a threat to democratic stability (Crozier et al., 1975) - today, however, it is a popular form of political engagement involving a considerable share of the people (Norris, 2002). It has been argued that these noninstitutionalized forms of participation are less demanding and more individual, leading to the expression of ill-considered and predominantly self-interested demands (Esaiasson, 2010), which suggests that they may be negatively associated with deliberative capacity. On the other hand, since non-institutionalized participation is in some kind of state of opposition to traditional political participation, we may assume that it is related to a demand for alternative forms of decision-making. Assuming that this is the case, the crucial question is whether those engaged in these forms of participation also possess deliberative capacity. A similar dummy variable as for the other two participation variables is included. ${ }^{3}$

Table 3 Civic and political participation, index of deliberative capacity and index dimensions. Mean values.

\begin{tabular}{|c|c|c|c|c|c|}
\hline $\begin{array}{l}\text { Civic and political } \\
\text { participation }\end{array}$ & $\begin{array}{l}\text { Percentag } \\
\text { e }\end{array}$ & $\begin{array}{r}\text { Deliberative } \\
\text { capacity }\end{array}$ & $\begin{array}{r}\text { Generalized } \\
\text { trust }\end{array}$ & Equality & $\begin{array}{r}\text { Other- } \\
\text { regarding }\end{array}$ \\
\hline \multirow{3}{*}{$\begin{array}{l}\text { Organizational } \\
\text { activity }\end{array}$} & Yes (12.1) & 3.29 & 1.31 & 1.10 & 0.89 \\
\hline & No (87.9) & 2.80 & 0.96 & 1.05 & 0.79 \\
\hline & & $* * *$ & $* * *$ & $* * *$ & $* * *$ \\
\hline \multirow{3}{*}{$\begin{array}{l}\text { Electoral } \\
\text { participation }^{1}\end{array}$} & Yes (77.5) & 2.92 & 1.04 & 1.06 & 0.82 \\
\hline & No (22.5) & 2.59 & 0.85 & 1.01 & 0.73 \\
\hline & & $* * *$ & $* * *$ & $* * *$ & $* * *$ \\
\hline \multirow{3}{*}{$\begin{array}{l}\text { Non- } \\
\text { institutionalized } \\
\text { participation }\end{array}$} & Yes (27.8) & 3.23 & 1.20 & 1.13 & 0.90 \\
\hline & No (72.2) & 2.71 & 0.93 & 1.02 & 0.76 \\
\hline & & $* * *$ & $* * *$ & $* * *$ & $* * *$ \\
\hline
\end{tabular}

Note: $* * *=$ significant at the 0.001 -level

${ }^{1}$ Only respondents with the right to vote are included.

In Table 3, mean values for those who have and those who have not taken part in these forms of activities are given. The level of deliberative capacity is higher in each form of participation compared to non-participation; the same is true with regard to each dimension. Neblo et al. (2010) found that those who are motivated to deliberate are less likely to vote in elections than those who lack motivation - this is not the case regarding the capacity to deliberate. Rather surprisingly, the largest difference appears between those who take part and those who do not take part in non-institutionalized activities. However, the highest level of deliberative capacity - 3.29 - prevails among those who are active in voluntary organizations. Generalized trust, in particular, is high among these citizens, which is quite natural since organizational activity and generalized trust is usually regarded as the main components of social capital. The degree of generalized trust is also considerably higher in the other two forms of participation as compared to non-participation.

The third explanatory model is called political competence; it consists of the variables political interest and internal efficacy. Interest in politics is a general prerequisite for all political activity. Therefore, one should be cautious of using political interest as an explanatory variable in these kinds of studies. Here, however, the dependent variable is not participation per se; rather, it concerns the conditions for engaging in a specific form of political procedure. The

3 See Appendix for details concerning the operationalization of the variables. 
decisive point is that political interest is not part of the concept of deliberative capacity. One can value equality for all, one can be other-regarding, and one can trust people that are different without taking a special interest in politics. Indirectly, however, we may assume that political interest is related to these attitudes and cognitive abilities because equality matters are regulated through politics, and trusting as well as understanding other people are social expressions which may be associated with political relations.

Internal political efficacy is a subjective measure of a person's evaluation of his/her political competence. It is a belief that one can understand politics and therefore participate in politics. It is not only concerned with skills and political knowledge but also with the ability to comprehend and resolve political problems. In addition, it deals with one's confidence in the ability to perform these tasks (e.g. Pateman, 1970; Mattei and Niemi, 2005). The capacity to justify one's own views and consider the arguments of others in a deliberative discussion will suffer if political competence is lacking. Political efficacy has been regarded as a determinant of voting behavior and voter turnout - similarly, it can be related to deliberative processes. In fact, a person with a lack of internal efficacy is ill-endowed to engage in deliberative political practices, which requires much more from the individual than, for instance, voting in elections. In a deliberative process, people must be able to interpret new facts and arguments correctly, and, furthermore, they have to be able to evaluate them critically. Accordingly, internal efficacy is expected to enhance deliberative capacity. Political interest is measured on a four- and internal efficacy is measured on a five-grade scale.

Table 4 Political competence, index of deliberative capacity and index dimensions. Correlation analysis.

\begin{tabular}{lrrrr}
\hline & $\begin{array}{r}\text { Deliberative } \\
\text { capacity }\end{array}$ & $\begin{array}{r}\text { Generalized } \\
\text { trust }\end{array}$ & Equality & $\begin{array}{r}\text { Other- } \\
\text { regarding }\end{array}$ \\
\hline Political interest & $.156^{* * *}$ & $.155^{* * *}$ & $.049^{* * *}$ & $.107^{* * *}$ \\
Internal efficacy & $.084^{* * *}$ & $.095^{* * *}$ & $.013^{* * *}$ & $.060^{* * *}$ \\
\hline Note: ${ }^{* * *}=$ significant at the 0.001 -level & & &
\end{tabular}

As we see in Table 4, both interest and efficacy are positively related to deliberative capacity as well as each of the three dimensions. Political interest is to a higher degree than internal efficacy associated with deliberative capacity, and of the dimensions, generalized trust is more strongly related to political competence than the other two. These findings are rather similar to those reported by Himmelroos (2012) with regard to activity and Neblo et al. (2010) concerning the willingness to deliberate. In the following, multivariate patterns are analyzed. All variables introduced above are included in the regression models in Table 5. Analyzing them separately (not presented in table format), the civic and political participation model has the largest explanatory power, whereas the other two are at a somewhat lower level. However, the explanatory power is small. The same is true of the combined models in Table 5 for the index of deliberative capacity as well as the single dimensions.

The most important variables explaining deliberative capacity are gender (female), education, non-institutionalized activity, and political interest. Theoretically, the last mentioned is the least interesting, and the importance of education comes as no surprise. Education provides citizens with many of the abilities that are needed in a deliberative discussion. Electoral and organizational activity has a positive effect on deliberative capacity, yet non-institutionalized activity clearly surpasses these two which is somewhat surprising. Non-institutionalized activity is a mode of citizen participation for the purpose of getting people's voices heard between and outside elections. The results suggest that citizens engaged in such activities, by 
contrast with those who are at ease with traditional forms of participation, may be enlightened in a different way and have skills appropriate for deliberation. Considering, first, that voter turnout has been on the decline and non-institutionalized activity has become more popular, and second, deliberative democracy is regarded as a complement to representative democracy, it is good news that this form of activity is positively associated with deliberative capacity. The difference in deliberative capacity between women and men is caused by higher scores on equality and other-regarding ability among women, which suggests that there are differences in empathic ability, feeling and understanding.

Table 5 Determinants of deliberative capacity. OLS regression.

\begin{tabular}{|c|c|c|c|c|}
\hline & $\begin{array}{r}\text { Deliberative } \\
\text { capacity }\end{array}$ & $\begin{array}{r}\text { Generalized } \\
\text { trust }\end{array}$ & Equality & $\begin{array}{r}\text { Other- } \\
\text { regarding }\end{array}$ \\
\hline \multirow[t]{3}{*}{ (constant) } & 2.022 & .611 & .902 & .513 \\
\hline & $(.026)$ & $(.013)$ & $(.013)$ & $(.013)$ \\
\hline & $78.996^{* * *}$ & $47.023^{* * *}$ & $67.583 * * *$ & $40.107^{* * *}$ \\
\hline \multirow[t]{3}{*}{ Age 15-29 } & .001 & .013 & -.006 & -.004 \\
\hline & $(.024)$ & $(.012)$ & $(.013)$ & $(.012)$ \\
\hline & .025 & 1.025 & -.457 & -.367 \\
\hline \multirow[t]{3}{*}{ Age 30-44 } & -.062 & -.012 & -.022 & -.027 \\
\hline & $(.021)$ & $(.011)$ & $(.011)$ & (.011) \\
\hline & $-2.926^{* *}$ & -1.146 & $-1.993^{*}$ & $-2.577^{* *}$ \\
\hline \multirow[t]{3}{*}{ Age 45-64 } & -.032 & -.024 & .005 & -.014 \\
\hline & $(.019)$ & $(-.015)$ & $(.010)$ & $(.010)$ \\
\hline & -1.699 & $-2.513^{*}$ & .515 & -1.438 \\
\hline \multirow[t]{3}{*}{ Gender $^{1}$} & .217 & -.011 & .105 & .119 \\
\hline & $(.014)$ & $(.007)$ & $(.007)$ & $(.007)$ \\
\hline & $15.174^{* * *}$ & -1.472 & $14.056^{* * *}$ & $16.609 * * *$ \\
\hline \multirow[t]{3}{*}{ Education } & .391 & .272 & -.008 & .123 \\
\hline & $(.023)$ & $(.012)$ & $(.012)$ & $(.012)$ \\
\hline & $16.641^{* * *}$ & $22.683^{* * *}$ & -.688 & $10.502^{* * *}$ \\
\hline \multirow{3}{*}{$\begin{array}{l}\text { Organizational } \\
\text { activity }\end{array}$} & .226 & .208 & .006 & .017 \\
\hline & $(.022)$ & $(.011)$ & $(.012)$ & $(.011)$ \\
\hline & $10.108^{* * *}$ & $18.216^{* * *}$ & .522 & 1.517 \\
\hline \multirow{3}{*}{$\begin{array}{l}\text { Electoral } \\
\text { participation }\end{array}$} & .149 & .100 & .017 & .034 \\
\hline & (.018) & $(.009)$ & $(.009)$ & $(.009)$ \\
\hline & $8.409^{* * *}$ & $.053^{* * *}$ & .070 & $3.840^{* * *}$ \\
\hline \multirow{3}{*}{$\begin{array}{l}\text { Non- } \\
\text { institutionalized } \\
\text { participation }\end{array}$} & .307 & .147 & .080 & .080 \\
\hline & $(.017)$ & $(.009)$ & $(.009)$ & $(.008)$ \\
\hline & $18.378^{* * *}$ & $17.221^{* * *}$ & $9.103^{* * *}$ & $9.525^{* * *}$ \\
\hline \multirow[t]{3}{*}{ Political interest } & .485 & .194 & .118 & .175 \\
\hline & $(.027)$ & $(.014)$ & $(.014)$ & $(.014)$ \\
\hline & $17.971^{* * *}$ & $14.076^{* * *}$ & $8.375^{* * *}$ & $12.942^{* * *}$ \\
\hline \multirow[t]{3}{*}{ Internal efficacy } & .149 & .049 & .019 & .078 \\
\hline & $(.027)$ & $(.014)$ & $(.014)$ & (.013) \\
\hline & $5.546^{* * *}$ & $3.594^{* * *}$ & 1.351 & $5.796^{* * *}$ \\
\hline R-square & .059 & .068 & .010 & .025 \\
\hline F-sig. & $* * *$ & $* * *$ & $* * *$ & $* * *$ \\
\hline $\mathbf{N}$ & 43075 & 44433 & 43393 & 43316 \\
\hline
\end{tabular}

Note: In each cell, from top downwards, figures indicate the regression coefficient, the standard error in brackets and the T-value, ${ }^{* * *}$ sig. $<0.001,{ }^{* *}$ sig. $<0.01, *$ sig. $<0.05$

All independent variables range from 0 - 1

${ }^{1}$ female $=1$, male $=0$ 


\section{CONCLUSION}

The main purpose of this article was to create a concept and a measure of deliberative capacity of individuals. The concept is based upon three dimensions - generalized trust, equality and other-regarding ability - that encompass essential cognitive and attitudinal characteristics needed. In a deliberative discussion, citizens benefit from interacting without mistrust towards people they do not know on a personal level, and believing that their intentions are good. Deliberation is guided by the principle of equality; it is a process of mutual justification where citizens approach each others on equal terms. The third dimension deals with the ability to understand and cooperate with people who are different. Good deliberation presupposes reciprocity, a fundamental respect for other people and their points of view, and critical selfreflection. On the basis of these three variables, a measure of deliberative capacity on a sevenpoint scale was constructed by means of survey data. One may argue that the cognitive, social and dynamic aspects of deliberation are too complex to capture by means of survey methods. However, the same procedure has been used in other related topics as well; therefore the procedure is considered justified. The analysis consisting of respondents from 26 European countries clearly showed that there are differences between individuals with regard to their deliberative capacity.

Empirically, generalized trust differed from the other two dimensions - the correlation between generalized trust, one the one hand, and equality and other-regarding ability, on the other, was rather weak on the basis of the data used - which calls into question whether generalized trust should be considered as a part of the deliberative capacity. It is first and foremost associated with social capital, yet it has been argued here that trusting people that we do not know is conceptually related to the attitudinal and cognitive ability of evaluating equality for all and understanding people that are different. Arguably, deliberative capacity is also related to social capital; we may assume that many people that possess social capital are also high on deliberative capacity. The problem in this regard is inadequate construct validity in the data available for the present. Theoretically, it has been claimed, generalized trust is an essential part of deliberative capacity.

The second purpose of the study was to examine the determinants of deliberative capacity. The explanatory power of the regression models was weak, yet the ambition has not been to provide a comprehensive explanatory framework of individual deliberative capacity. The empirical analysis showed that there are differences in deliberative capacity, albeit not very immense, with regard to those determinants that have been analyzed. The deliberative capacity consistently increases with higher education, women score on average better than men, and people involved in associational activities and voting in elections have greater deliberative skills. Interestingly, individuals engaged in non-institutional forms of participation have a considerably higher level of deliberative capacity than others. Political interest is positively related, whereas internal efficacy is not as strongly associated with deliberative capacity as one might expect. 


\section{APPENDIX}

Index of deliberative capacity

Data from ESS-4 2008:

Variable 1: Most people can be trusted or you can't be too careful in dealing with people

Using this card, generally speaking, would you say that most people can be trusted, or that you can't be too careful in dealing with people? Please tell me on a score of 0 to 10, where 0 means you can't be too careful and 10 means that most people can be trusted.

Values from 0 to 3 (30.0 percent of all respondents) are recoded into 0, values from 4 to 6 (39.7 percent of all respondents) are recoded into 1, and values from 7 to 10 (30.3 percent of all respondents) are recoded into 2 .

Variable 2: It is important that people are treated equally and have equal opportunities

$\mathrm{He}$ /she thinks it is important that every person in the world should be treated equally. He/she believes everyone should have equal opportunities in life.

Very much like me 1; Like me 2; Somewhat like me 3; A little like me 4; Not like me 5; Not like me at all 6

Values from 3 to 6 (26.7 percent of all respondents) are recoded into 0, value 2 (41.2 percent of all respondents) is recoded into 1 , and value 1 (32.1 percent of all respondents) is recoded into 2 .

Variable 3: It is important to understand different people

It is important to him/her to listen to people who are different from him/her. Even when he/she disagrees with them, he/she still wants to understand them.

Very much like me 1; Like me 2; Somewhat like me 3; A little like me 4; Not like me 5; Not like me at all 6

Values from 3 to 6 (39.2 percent of all respondents) are recoded into 0, value 2 (41.5 percent of all respondents) is recoded into 1 , and value 1 (19.3 percent of all respondents) is recoded into 2 .

\section{Voted in last legislative elections}

Some people don't vote nowadays for one reason or another. Did you vote in the last [country] national election in [month/year]?

Yes 1 ; No 0

\section{Activity in voluntary organizations}

There are different ways of trying to improve things in [country] or help prevent things from going wrong. During the last 12 months, have you done any of the following? Have you worked in another organisation or association?

Yes 1; No 0

\section{Non-institutionalized political participation}

There are different ways of trying to improve things in [country] or help prevent things from going wrong. During the last 12 months, have you done any of the following? Have you...

Signed a petition?

Taken part in a lawful public demonstration?

Boycotted certain products?

A dummy is constructed, distinguishing between those who have performed at least one of the actions from those have not performed any of these actions.

\section{Political interest}

How interested would you say you are in politics?

Very interested 4; quite interested 3; hardly interested 2; not at all interested 1

\section{Internal political efficacy}

How often does politics seem so complicated that you can't really understand what is going on? Never 5; seldom 4; occasionally 3; regularly 2; frequently 1 


\section{References}

Barber, B. (1984). Strong Democracy: Participatory Politics for a New Age. Los Angeles: University of California Press.

Benhabib, S. (1996). Toward a Deliberative Model of Democratic Legitimacy, in S. Benhabib, ed., Democracy and Difference: Contesting the Boundaries of the Political. Princeton: Princeton University Press, pp. 67-94.

Bohman, J. (1996). Public Deliberation. Pluralism, Complexity and Democracy. Cambridge: The MIT Press.

Bäck, M. (2011). Socialt kapital och politiskt deltagande i Europa. Åbo: Åbo Akademi University Press.

Chambers, S. (1996). Reasonable Democracy. Ithaca: Cornell University Press.

Cohen, J. (1989). Deliberation and Democratic Legitimacy, in A. Hamlin and P. Pettit, eds, The Good Polity: Normative Analysis of the State. Cambridge: Basil Blackwell, pp. 17-34.

Cohen, J. (2007). Deliberative Democracy, in S.W. Rosenberg, ed., Deliberation, Participation and Democracy: Can the People Govern. New York: Palgrave Macmillan, pp. 219-36.

Crozier, M., Huntington, S.P. and Watanuki, J. (1975). The Crisis of Democracy: Report on the Governability of Democracies to the Trilateral Commission. New York: New York University Press.

Delli Carpini, M.X., Cook, F.L. and Jacobs, L.R. (2004). Public Deliberation, Discursive Participation, and Citizen Engagement. Annual Review of Political Science 7: 315-44.

Dryzek, J.S. (2000). Deliberative Democracy and Beyond: Liberals, Critics, Contestations. Oxford: Oxford University Press.

Dryzek, J.S. (2005). Handle with Care: the Deadly Hermeneutics of Deliberative Instrumentation. Acta Politica 40: 197-211.

Dryzek, J.S. (2007). Theory, Evidence, and the tasks of Deliberation, in S.W. Rosenberg, ed., Deliberation, Participation and Democracy: Can the People Govern? Basingstoke: Palgrave Macmillan, pp. 237-50.

Dryzek, J.S. (2009). Democratization as Deliberative Capacity Building. Comparative Political Studies 42(11): 1379-402.

Eliasoph, N. (1998). Avoiding Politics: How Americans Produce Apathy in Everyday Life. New York: Cambridge University Press.

Elster, J. (1986). The Market and the Forum: Three Varieties of Political Theory, in J. Elster and A. Hylland, eds, Foundations of Social Choice Theory. Cambridge: Cambridge University Press.

Esaiasson, P. (2010). Is Citizen Involvement Always a Plus?, in E. Amna, ed., New Forms of Citizen Participation. Normative Implications. Baden-Baden: Nomos.

ESS Round 4: European Social Survey Round 4 Data (2008). Data file edition 4.0. Norwegian Social Science Data Services, Norway - Data Archive and distributor of ESS data.

Fishkin, J.S. (1997). The Voice of the People: Public Opinion and Democracy. New Haven: Yale University Press.

Fishkin, J.S., Luskin, R.C. and Jowell, R. (2002). Considered Opinions: Deliberative Polling in Britain. British Journal of Political Science 32: 455-87.

Fung, A. (2007). Minipublics: Deliberative Designs and Their Consequences, in S.W. Rosenberg, ed., Deliberation, Participation and Democracy: Can the People Govern? Basingstoke: Palgrave Macmillan, pp. 159-83.

Gastil, J. and Levine, P. (2005). The Deliberative Democracy Handbook: Strategies for Effective Civic Engagement in the Twenty-First Century. San Francisco: Jossey-Bass.

Grönlund, K. and Milner, H. (2006). The Determinants of Political Knowledge in Comparative Perspective. Scandinavian Political Studies 29(4): 386-406.

Grönlund, K., Strandberg, K. and Himmelroos, S. (2009). The Challenge of Deliberative Democracy Online: A Comparison of Face-to-Face and Virtual Experiments in Citizen Deliberation. Information Polity 14: 187-201. 
Grönlund, K., Setälä, M. and Herne, K. (2010). Deliberation and Civic Virtue: Lessons from a Citizen Deliberation Experiment. European Political Science Review 2(1): 95-117.

Gutmann, A. and Thompson, D. (1996). Democracy and Disagreement. Cambridge: Harvard University Press.

Gutmann, A. and Thompson, D. (2004). Why Deliberative Democracy? Princeton, NJ: Princeton University Press.

Himmelroos, S. (2012). Det demokratiska samtalet: en studie av deliberativ demokrati i ett medborgarforum. Åbo: Åbo Akademi University.

Human Development Reports. Internet retrieved http://hdr.undp.org/en/

Jacobs, L.R., Cook, F.L. and Delli Carpini, M.X. (2009). Talking Together. Public Deliberation and Political Participation in America. Chicago: The University of Chicago Press.

Luskin, R.C., Fishkin, J.S. and Jowell, R. (2002). Considered Opinions: Deliberative Polling in Britain. British Journal of Political Science 32: 455-87.

Mansbridge, J. (1983). Beyond Adversary Democracy. Chicago: Univ. Chicago Press.

Mansbridge, J. (1990). Beyond Self-Interest. Chicago: Univeristy of Chicago Press.

Mastekaasa, A. (1987). Modellbruk, indekser og konsistenskriterier. Tidsskrift for samfunnsforskning 28: 167-88.

Mattei, F. and Niemi, R.G. (2005). Political Efficacy, in S. Best and B. Radcliffe, eds, Polling America: An Encyclopedia of Public Opinion. Westport, CT: Greenwood Press.

McKnight, D.H. and Chervany, N.L. (2011). Conceptualizing Trust: A Typology and E-Commerce Customer Relationships Model. Proceedings of the 34th Hawaii Conference on System Sciences 2001.

Mendelberg, T. (2002). The Deliberative Citizen: Theory and Evidence, in M.X. Delli Carpini, L. Huddy and R.Y. Shapiro, eds, Political Decision Making, Deliberation and Participation. Bradford: Emerald Group Publishing Limited, pp. 151-93.

Mendelberg, T. and Karpowitz, C. (2007). How People Deliberate about Justice: Groups, Gender, and Decision Rules, in S. Rosenberg, ed., Deliberation, Participation and Democracy. Palgrave: Basingstoke, pp. 101-29.

Morrell, M.E. (2005). Deliberation, Democratic Decision-Making and Internal Political Efficacy. Political Behavior 27(1): 49-69.

Mutz, D.C. (2008). Is Deliberative Democracy a Falsifiable Theory? Annual Review of Political Science 11: 521-538.

Neblo, A.M., Esterling, K.M., Kennedy, R.P., Lazer, D.M.J. and Sokhey, A.E. (2010). Who Wants to Deliberate - And Why? American Political Science Review 104(3): 566-83.

Nie, N.H., Junn, J. and Stehlik-Barry, K. (1996). Education and Democratic Citizenship in America. Chicago: University and Chicago Press.

Norris, P. (2002). Democratic Phoenix. Reinventing Political Activism. Cambridge: Cambridge University Press.

Parkinson, J. (2006). Deliberating in the Real World: Problems of Legitimacy in Deliberative Democracy. Oxford: Oxford University Press.

Pateman, C. (1970). Participation and Democratic Theory. New York: Cambridge University Press.

Putnam, R.D. (2000). Bowling Alone: the Collapse and Revival of American Community. New York: Simon and Schuster.

Rawls, J. (1971). A Theory of Justice. Cambridge, Mass.: Harvard University Press.

Rosenberg, S.W. (2007). An Introduction: Theoretical Perspectives and Empirical Research on Deliberative Democracy, in S.W. Rosenberg, ed., Deliberation, Participation and Democracy: Can the People Govern. New York: Palgrave Macmillan, pp. 1-24.

Rothstein, B. (2003). Sociala fällor och tillitens problem. Stockholm: SNS Förlag.

Rothstein, B. and Stolle, D., eds, (2003). Generating Social Capital. Civil Society and Institutions in Comparative Perspective. New York: Palgrave Macmillan. 
Smith, G. (2005). Power beyond the Ballot. 57 Democratic Innovations from Around the World. London: The Power Inquiry.

Smith, G. and Wales, C. (2000). Citizens' Juries and Deliberative Democracy. Political Studies 48: 51-63.

Steenbergen, M.R., Bächtiger, A. Spörndli, M. and Steiner, J. (2003). Measuring Political Deliberation: a Discourse Quality Index. Comparative European Politics 1: 21-48.

Steiner, J., Bächtiger, A., Spörndli, M. and Steenbergen, M.R. (2004). Deliberative Politics in Action. Analyzing Parliamentary Discourse. Cambridge: Cambridge University Press.

Stokes, S. (1998). Pathologies of Deliberation, in J. Elster, ed., Deliberative Democracy. Cambridge: Cambridge University Press, pp. 123-39.

Thompson, D.F. (2008). Deliberative Democratic Theory and Empirical Political Science. Annual Review of Political Science 11: 497-520.

Uslaner, E.M. (2002). The Moral Foundations of Trust. Cambridge: Cambridge University Press.

Verba, S., Schlozman, K.L. and Brady, H.E. (1995). Voice and Equality: Civic Voluntarism in American Politics. Cambridge, MA: Harvard University Press.

Walsh, K.C. (2007). The Democratic Potential of Civic Dialogue, in S.W. Rosenberg, ed., Deliberation, Participation and Democracy: Can the People Govern. New York: Palgrave Macmillan, pp. 45-63.

Warren, M.E. (1992). Democratic Theory and Self-Transformation. American Political Science Review 86: 8-23.

Warren, M.E., ed., (1999). Democracy and Trust. Cambridge: Cambridge University Press.

Young, I. (1996). Communication and the Other: Beyond Deliberative Democracy, in S. Benhabib, ed., Democracy and Difference: Contesting the Boundaries of the Political. Princeton: Princeton University Press, pp. 120-36. 